\title{
AN ANALYSIS OF THE USE OF TECHNOLOGY MANAGEMENT ACTIVITIES FOR TECHNOLOGY OPTIMISATION: A CASE IN THE BANKING INDUSTRY
}

\author{
S.P. Leuta ${ }^{1} \&$ M.W. Pretorius ${ }^{1 *}$
}

\section{ARTICLE INFO}

\section{Article details}

Submitted by authors 27 Jul 2018 Accepted for publication 15 Nov 2019 Available online $\quad 12$ Dec 2019

\section{Contact details}

* Corresponding author

Tinus.pretorius@up.ac.za

Author affiliations

1 Department of Engineering and Technology Management, Graduate School of Technology Management, University of Pretoria, South Africa

\section{DOI}

http://dx.doi.org/10.7166/30-4-1994

\section{ABSTRACT}

Technology in the banking industry plays a key role in driving strategic business decisions. Technology acquisitions often do not result in optimal technology utilisation as measured by the number of innovations being logged, failure incidents in operations, and customer feedback ratings. The study investigates how technology management activities are carried out, with the emphasis on the acquisition and learning activities. A research model containing the elements of (i) technology acquisition effort, (ii) learning effort, (iii) innovative capacity, (iv) technology management tools limiting factors, and (v) technology optimisation was used to determine the inter-relationships between the elements. The research followed a mixed methods approach in which a quantitative study in the form of a survey, followed by qualitative interviews, was used. The research results confirmed the importance of the technology management activities and the need for coupling such activities. The study also identified shortcomings in terms of feedback loops in the technology management lifecycles.

\section{OPSOMMING}

Tegnologie in die bankbedryf speel 'n sleutelrol in strategiese besluitneming. Nuwe tegnologie wat aangeskaf word maak dikwels nie ' $n$ optimale bydrae tot tegnologie benutting nie, soos gemeet aan die aantal innovasies wat realiseer, faling-insidente in die bedryfsaktiwiteite, en kliënt terugvoering graderings. Hierdie studie ondersoek hoe tegnologiebestuursaktiwiteite uitgevoer word met die klem op aanskaffing en leeraktiwiteite. 'n Navorsingsmodel wat die elemente (i) tegnologie aanskaffingspoging, (ii) leerpoging, (iii) innovasie kapasiteit, (iv) beperkende faktore van tegnologiebestuursgereedskap, en (v) tegnologie-optimisasie bevat, is gebruik om die verwantskappe tussen die elemente te bepaal. 'n Gemengde navorsingsmetode benadering is gevolg - naamlik, 'n kwantitatiewe opname gevolg deur kwalitatiewe onderhoude. Die resultate bevestig die belangrikheid van tegnologiebestuursaktiwiteite en die behoefte om dit aan die toepaslike fases in die lewensiklus te koppel.

\section{INTRODUCTION}

Technology as a capability is regarded as an important role player in innovation. Technological capability is about linking together people, knowledge, tools, and systems for the betterment of firms and society. These dimensions are connected through the knowledge and skills that people possess to operate the systems, rules, and algorithms that contain the knowledge and the tools that are used in the process [1]. The financial sector uses technology not only for core operations, but also as a source of competitiveness and innovative capacity. Eisenhardt and Martin [2] argue that competitive advantage lies in the configurations of resources that capabilities create rather than in the resources themselves. In the bank under study, the Data Warehouse and Support Services division (DWSS) functions as a key data hub within the banking group. It is responsible for sourcing and 
transforming an array of data sources for downstream applications used in the group. This also includes storing the data for future reference and regulatory purposes. Figure 1 shows a simplified diagram of the DWSS source systems.

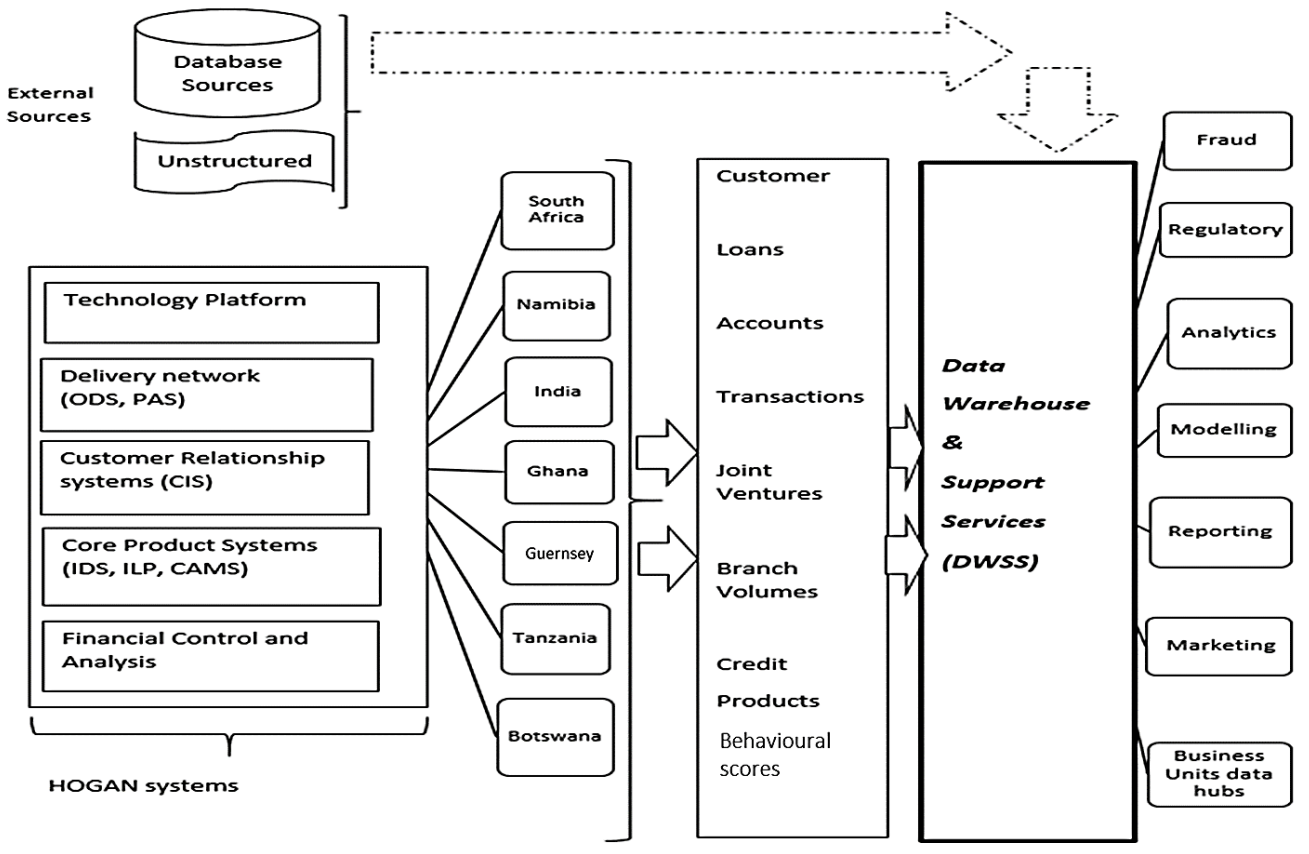

Figure 1: The simplified DWSS source systems

The technology acquisition processes that are based on collaboration between the industry and external partners do not always result in optimal technology utilisation as measured by (i) the number of innovations logged in organisational logging platforms, (ii) the number of failure incidents in production, and (iii) customer feedback ratings. To address these shortcomings, the following research questions were formulated: (i) How can technology management activities be used to optimise technology utilisation in the banking industry? (ii) How can technology acquisition processes be optimised? (iii) What factors hinder the effective use of TM tools in the banking industry? and (iv) What impact does technology acquisition have on the innovative capacity of the organisations? The rest of the article is structured as follows: In the next section we discuss the underlying theory that supports the research approach. It is followed by sections 3 and 4 , in which we describe the proposed research model and research methodology. In section 5 we present the results and substantiate the findings of the research. In section 6 the paper is concluded with proposed recommendations and suggestions for further research.

\section{LITERATURE REVIEW}

In the traditional view of technology management framework, Çetindamar, Phaal and Probert [3] describe technology management as the management of dynamic capabilities to achieve the strategic and operational objectives of the organisation. These dynamic capabilities are based on the organisational ability to integrate, build, and reconfigure internal and external competences to address rapidly changing market conditions, thus making it a source of sustainable competitive advantage [4]. Firms therefore need to build irreplaceable, hard-to-imitate, and distinctive capabilities to achieve sustained competitive advantage. In more recent developments in the body of knowledge on innovation management, the role of innovation ecosystems as structures for value co-creation in firms have attracted the attention of researchers [5]. Adner [6] describes innovation ecosystems as collaborative arrangements through which firms combine their individual offerings into a coherent, customer-facing solution. In relation to the banking industry, this means that sustainable competitive advantage is achieved not only by the volume of technologies that companies own, but also by their ability to acquire, transfer, and modify their behaviour to reflect 
the new knowledge and insights. Thus merely devoting resources to innovation-related activities is not sufficient; and many would still fail, regardless of the investments.

Based on the traditional technology management activities framework, as well as the underlying theory of innovation ecosystems, this study focused on the role and management of technology acquisition and learning activities. Mortara and Ford [7] argue that organisations' ambitions to acquire technology can be categorised into strategic, gaining efficiency, developing new technologies, and responding to competitive environments. The banking sector is faced with similar challenges, and acquires technology through quasi-external activities such as technology alliances and fully fledged external activities such as inward licensing and purchasing patents. Tsai and Wang [8] state that internal acquisition provides competitive advantage through building internal development capacity, thus allowing more absorptive capabilities of externally acquired knowledge. Similarly, external acquisition enables tacit and codified knowledge inflows into the organisation from multiple partners outside its boundaries. This also allows for risk aversion through transferring it to external partners and eliminating huge capital expenditure on setting up R\&D facilities for specialised skills and research.

In this regard, DWSS works in collaboration with partner networks that share and conduct market surveillance for potentially disruptive technologies, or with those that have made breakthroughs in other markets and that could be customised to local environments. This presents the department with the best opportunities to acquire innovative technologies ahead of its peers. Yu [9] argues that firms' absorptive capacity tend to enhance their learning capabilities, which results in the effective use of external knowledge for problem-solving activities and creating novelty. Farrukh and Waheed [10] are of the view that, without continuous learning, any gains achieved through acquisition will be short-lived and non-sustainable. This suggests that, in the case of DWSS, technology alone cannot be a source of competitive advantage; nor can it ensure that technology utilisation is based on its intended purposes. Appelbaum and Gallagher [11] concur with this point, and posit that investing in technology, although critical, should not be considered as a key source of competitive advantage; instead organisations need to be investing in people with know-how that can use the technologies productively. A similar view is shared by Kang et al. [12], that over-reliance on external technology can be disadvantageous to the organisation's technological competence - mainly because, beyond a certain point, an inverted ' $U$ ' relationship develops between technology innovation and performance output. As such, organisations need to be in a continuous learning phase to exploit the acquired knowledge. Boerner et al. [13] view learning as the acquisition of knowledge and as using existing knowledge to enhance organisational competitiveness. A similar view is shared by Çetindamar et al. [14]: that learning organisations need to be skilled in acquiring and internalising the acquired knowledge to reflect the new knowledge and insights. According to Zollo and Winter [15], this requires the co-evolution of three learning mechanisms: learning articulation, knowledge codification, and experience accumulation. First, 'knowledge articulation' happens when members express their opinions and beliefs and engage in constructive confrontations, challenging each other's point of views. Second, 'knowledge codification' refers to the process of transferring tacit knowledge to explicit knowledge in a reusable form for an organisation's members. Through this process, the logical steps in one's argument are codified, and hidden assumptions and unearthed and causal links are made explicit. Last, 'experience accumulation' refers to the tacit accumulation of knowledge through experimentation and trial-and-error learning over a given period.

In making decisions on technology acquisitions, Çetindamar et al. [14] argue that technology management tools are needed. This entails a plethora of tools, methods, and techniques that organisations apply to achieve their required objectives. Of interest are technology space maps and s-curves. This interest is driven by their relevance to the research study; and they assist the DWSS in achieving its mandate of being a single point of reference for all data requirements by acquiring the best technologies and ensuring that they are optimally used. De Wet [16] posits that technology space maps can assist as a form of shorthand communication about technology to non-technologists, and can help in making strategic decisions about technology acquisition by identifying current technology capabilities, mapping them to future desired capabilities, and developing transfer skills to fill the gaps identified in the process. Similarly, s-curves are strategic decision-making tools that can assist organisations to make critical decisions on when to switch from the base technology to the emerging technologies. However, the banking industry is known to be highly-regulated; and this is reflected in its internal procedures as well - for example, in the adoption of decision frameworks and business models. This behaviour could have an significant impact on its ability to adopt the use 
of technology and innovation management tools, and will have an impact on the need to build internal innovative capacity and to use integrated technology management frameworks.

Çetindamar et al. [14], on the other hand, argue that a chief technology officer's field of education and position in the organisation's hierarchy also play a key role. This is because CTOs with a deep knowledge of core technologies in the sector can use several tools to achieve their objectives. Similarly, a higher level in the organisational structure of the CTO means that less time is allocated to the management of technological activities - unlike those that are lower in the firm's hierarchy, who are eager to improve their technological capabilities and to use more TM tools. Foden and Berends [17] identify three dimensions -ownership, timing, and input/output from one toolset to the next - as prerequisites to ensuring that TM activities leverage each other. They argue that confusion about the ownership of tools creates a lack of accountability, and demotivates the use of TM tools. Timing guides the opportune moment to acquire the right tools at the right stage of their s-curve cycle, because it is no point in using selection activity tools when the product is already in the decline stage.

As an approach, 'dynamic capabilities' (DC) dictates that organisations no longer enjoy long-term competitive advantage. Instead, they are required to continuously build their knowledge base and innovation capabilities. Thus absorptive capacity is required for organisations to tap into the knowledge base from inside and outside the organisation (Liao et al. [18]) to build their innovation capabilities. After knowledge acquisition has taken place, other sub-activities, such as knowledge transfer and integrating the technology into the organisational processes, must happen to build internal capacity. Neely and Hii [19] argue that innovative capacity is driven by a firm's culture, competences, resources, and networks. Culture dictates what is valued within the organisation. Competence, on the other hand, requires technological abilities, problem-solving skills, experimentation, and sharing of tacit knowledge. Thus it follows that innovative capacity is dependent on the process of learning, searching, and exploring; and, without those, such capabilities cannot be realised.

\section{CONCEPTUAL RESEARCH MODEL AND HYPOTHESES}

The conceptual research model is shown in Figure 2. The following variables were identified:

Key variable

Technology acquisition efforts

Learning efforts

Innovative capacity

TM limiting factors

Technology optimisation

\section{Dimensions}

Use of TM tools:

Space maps and s-curve

Experience accumulation, knowledge articulation, knowledge codification
Absorptive capacity
Education level and
Independent
Independent years of work experience

Number of incidents generated, number of innovations logged, system uptime, system processing time, customer feedback ratings

\section{Variable type}

Independent

Independent

Dependent 


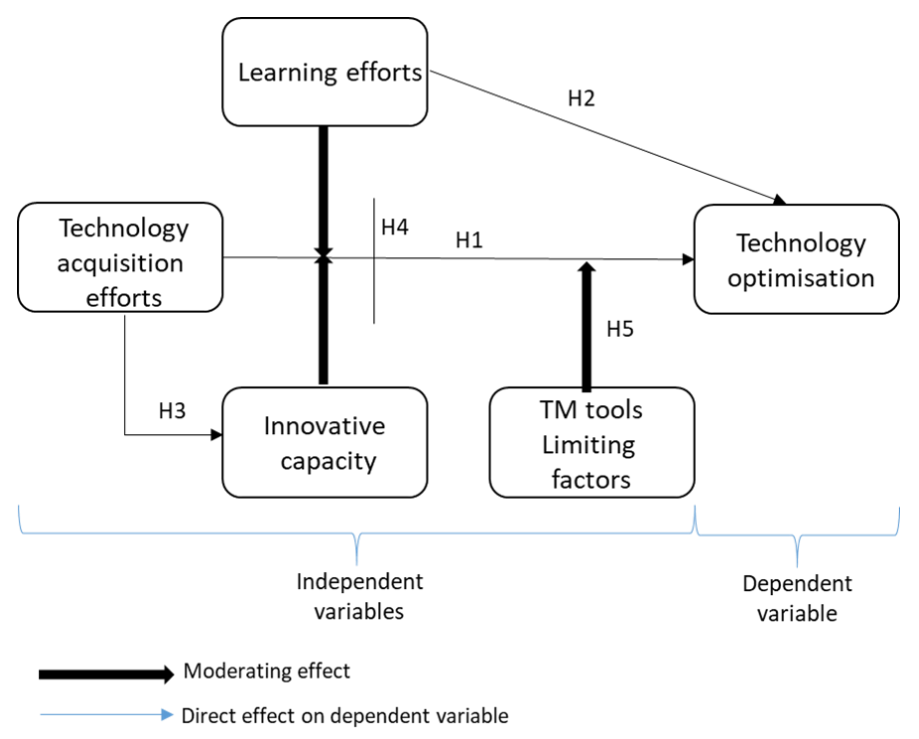

Figure 2: Proposed conceptual model

Technology acquisition efforts and technology optimisation: According to Çetindamar, et al [3], 'technology acquisition' refers to the acquisition of knowledge through either internal or external sources. Therefore, to ascertain correctly whether the new knowledge matches the organisation's required capabilities, technology audits that identify the current technology capabilities and that map them to future technological requirements are necessary. These provide the organisation with a clear picture of the value of the technology and of its potential capabilities. Similarly, s-curves allow the organisation to make an informed decision based on the stage of the technology and the organisational goals at that point in time. Consequently, the TM tools' efforts in using space maps and s-curves have a positive effect on technology optimisation.

\section{H1: The use of space maps and s-curves in technology acquisition has a positive effect on technology optimisation in the bank under study.}

Learning efforts and technology optimisation: Learning, according to Jiménez-Jiménez and SanzValle [20], improves an organisation's competency base, organisational skills, and assimilative capacity. Thus it increases organisational competency levels and enables a conducive environment for tacit and codified knowledge to be transferred among peers. This is true because, when employees are competent, they can share knowledge freely, thus enabling technology optimisation. Of the three mechanisms of learning that Zollo and Winter [15] mentioned as key, "knowledge codification' is particularly crucial because a significant portion of the core technologies in DWSS is based on legacy systems. This means that knowledge and expertise reside with ageing senior personnel who need to transfer the knowledge to the incoming generation while maintaining quality and standards of work.

\section{H2: The learning dimensions of knowledge codification, knowledge articulation, and experience accumulation have a positive effect on technology optimisation in the bank under study.}

Technology acquisition's effect on innovative capacity: Innovative capacity can be considered as the potential of an organisation to generate innovative output [19]. Such potential can be derived from external and internal resource acquisitions. Tsai and Tsai [21] view innovative capability as a basic requirement of any organisation that intends to improve its performance. As such, it appears that there is a direct correlation between technology acquisition and innovative capacity. This is because, through acquisition processes, new skills and capabilities are brought into the firm. Liao et al. [18] argue that there is a relationship between the absorptive capacity of the firm the knowledge acquisition; and further, that knowledge acquisition is an antecedent factor to absorptive capacity. This seems to indicate that, if technology acquisition processes can be optimised, there will be a positive effect on the innovative capability of the organisation. 


\section{H3: Improvement of the technology acquisition process has a positive effect on the innovative capacity of the bank under study.}

Moderating role of learning and innovative capacity: Cohen and Levinthal [22] consider absorptive capacity as the ability to assimilate, transform, and recognise the value of new knowledge. In essence this implies that sourcing technology is not a panacea, but that extra competencies are required to transform the information to reflect the new acquired knowledge. Liao et al. [18] state that organisations with absorptive capacity have a high innovative capacity. According to Yeșil et al. [23], having innovative capabilities implies the ability to create new possibilities, improve current technologies beyond their original design parameters, and continuously to invent innovative outcomes. It therefore appears that innovative capacity and absorptive capacity have a moderating effect on the relationship between technology optimisation and acquisition.

\section{H4: Learning and innovative capabilities in the bank under study have a moderating effect on the relationship between technology acquisition and optimisation.}

Moderating role of TM tools use on optimisation: High levels of training combined with experience of core technologies contribute to the positive use of TM tools. This is because high education levels build critical thinking and a systematic approach to problem-solving; and levels of experience build tacit knowledge of the subject matter. When combined, both build the necessary capabilities to integrate isolated tool sets in the organisation into a consolidated view. Without integration, Foden and Berends [17] argue that tools are often used in isolation, and so provide sub-optimal results due to the failure to complement each other. Magoutas et al. [24] agree with these views, and argue that education significantly increases the performance of firms. In the banking industry, many of the specialists have basic levels of education but many years of experience; and this often limits their perspectives, as they are more concerned about their speciality than about looking at the bigger picture of the overall organisational objectives.

\section{H5: Higher levels of education and work experience of employees in the bank under study have a moderating effect on the effective use of TM tools and consequently on technology optimisation.}

\section{RESEARCH METHODOLOGY}

The research was conducted in the DWSS division of a large South African bank. A case study approach was followed. The process used to collect and analyse the research data was based on proven research methodologies obtained from scholarly literature [25] - [33]. A mixed method research approach that included both qualitative and quantitative methods was applied. Data collection was based on random purposive sampling in order to ensure that a random yet in-depth analysis was done. A sample of 85 online questionnaires were distributed to managers and team leaders in the four groups of WDSS: Infrastructure Support, Production Support, Development, and Quality Testing. The questionnaire can be viewed in the Appendix. Forty-two responses were received, giving a response rate of 49 per cent. The online survey was followed by four qualitative interview sessions. The qualitative data analysis process was conducted through an inductive data approach, which allowed for ideas and concepts to be established from the transcribed data. AtlasTI software was used to develop a coding framework.

\section{RESULTS AND DISCUSSION}

\subsection{Quantitative analysis}

The internal consistency was calculated using Cronbach's alpha. The minimum accepted value is 0.6 , while the values obtained from the calculations averaged 0.754 (see Table 1 ) indicating that the questions were reliable and valid for the study. 
Table 1: Cronbach's alpha results for internal consistency

\begin{tabular}{|c|c|c|c|}
\hline Variable & Items & Source & Cronbach's a \\
\hline $\begin{array}{l}\text { Technology acquisition } \\
\text { efforts }\end{array}$ & $\begin{array}{l}\text { 1. Technology management tools } \\
\text { being used } \\
\text { 2. Skills audit exercises done } \\
\text { 3. Technology acquisitions bring new } \\
\text { skills } \\
\text { 4. Right technologies being acquired } \\
\text { 5. Technology switch before } \\
\text { becoming obsolete }\end{array}$ & $\begin{array}{l}\text { (Çetindamar et al., } \\
2010) \\
\text { (Zollo and Winter, } \\
\text { 2002) }\end{array}$ & $a=0.747$ \\
\hline Learning efforts & $\begin{array}{l}\text { 1. Knowledge sharing among } \\
\text { different teams } \\
\text { 2. Cross-functional teams' } \\
\text { collaboration } \\
\text { 3. Skills/knowledge transfer being } \\
\text { prioritised } \\
\text { 4. Knowledge codification being } \\
\text { done }\end{array}$ & $\begin{array}{l}\text { (Popadiuk et al., } \\
\text { 2009) }\end{array}$ & $a=0.764$ \\
\hline $\begin{array}{l}\text { Innovative capability } \\
\text { efforts }\end{array}$ & $\begin{array}{l}\text { 1. Search for innovative ways } \\
\text { 2. Log innovative ideas } \\
\text { 3. Implement new ideas }\end{array}$ & $\begin{array}{l}\text { (Liao et al., 2010) } \\
\text { (Popadiuk et al., } \\
\text { 2009) }\end{array}$ & $a=0.802$ \\
\hline $\begin{array}{l}\text { Technology usage } \\
\text { hindrances }\end{array}$ & $\begin{array}{l}\text { 1. Business operation model reverse } \\
\text { 2. Too many standalone systems } \\
\text { reverse } \\
\text { 3. Organisational systems and } \\
\text { processes reverse }\end{array}$ & $\begin{array}{l}\text { (Cetindamar et al., } \\
\text { 2012) } \\
\text { (Foden and Berends, } \\
\text { 2010) }\end{array}$ & $\alpha=0.706$ \\
\hline
\end{tabular}

Similarly, central tendency was calculated. This followed the quantitative data collection, which was based on Likert scale types of question. Two five-point Likert scale designs were used, with the options being either (i) Strongly disagree, Disagree, Neither agree or disagree, Agree, Strongly agree, or (ii) Never, Rarely, Sometimes, Often, Always, as can be seen in the Questionnaire in the Appendix. The data obtained was ordinal data; and while median and mode provided values for this calculation, it was only appropriate to use the median because of the ordinal nature of the data. An average median value of 3 across the dimensions was obtained, indicating a neutral response across the respondents. This was probed later in the interview process, as reported later in the discussion. In contrast, the innovative capability dimension had a value of 3.50 , which could be interpreted as a 4 for 'Agree' on Likert scale. Descriptive analyses were also undertaken for each of the dimensions, and the following key points were derived from each of the dimensions:

\subsubsection{Dimension: Technology acquisition efforts}

- $\quad$ About 40 per cent of the respondents agreed that technology management tools were being used across the department.

- More than 60 per cent of them felt that technology brought new skillsets to the department.

- As few as 10 per cent of the respondents agreed that skills audit exercises were being done.

- $\quad$ Around 40 per cent of the respondents agreed that the right technologies were being acquired. The rest either disagreed or remain neutral. This corresponds to the previous point - the disconnect between the needs of the organisation and the acquired technology.

\subsubsection{Dimension: Learning efforts}

- Low levels of collaboration, as indicated by only about 30 per cent of the respondents agreeing that there was some form of collaboration in the teams.

- A similar trend was noticed for collaborations across different functional teams.

- Low percentages - as low as 20 per cent of the respondents - were noted on the codification of knowledge.

- $\quad$ Slightly better responses were realised on skills knowledge transfer coming with the new technology.

- $\quad$ Post-implementation reviews showed a low number of respondents agreeing that they had been carried out, with an extra 10 per cent of the respondents choosing 'strongly disagree'. The findings seem to suggest that teams or individuals were working in silos; and this could have a negative impact on the technological exploitation capabilities of the organisation.

\subsubsection{Dimension: Innovative capacity}

- A considerably high percentage of respondents were conducting research on innovative ways of doing things and implementing new ideas. 
- $\quad$ About 10 per cent of the respondents never logged innovations on platforms provided by the organisation - this despite searching for and implementing innovative ways in the organisation.

- $\quad$ Significant increases - as much as 19 per cent of the respondents - responded with 'strongly agree' attitudes. However, the 10 per cent of the respondents who chose 'strongly disagree' with respect to logging innovations appears to be consistent with an earlier observation - that a high percentage of the respondents seem to be working in silos. This is because logging the innovation would require knowledge sharing and codification of the knowledge; and that appeared not to be favoured by the respondents.

\subsubsection{Dimension: Usage of technology management limiting factors}

- As many as 40 per cent of the respondents believed that organisational systems and processes had a limiting effect on TM tools.

- This could be attributed to the highly regulated environment in which the banking sector operates, which requires that systems and processes follow strict approval processes before being used.

- Having higher levels of education was found to have a slightly higher impact on TM tools than having many years of working experience.

- This could be because employees with higher levels of experience believe in their tried and tested ways, and changing to new tools would require re-learning and potentially relinquishing their competitive advantage.

- A consistently significant number of the respondents remained neutral.

Table 2 summarises the outcomes of the dimensions and the responses.

Table 2: Heat map indicating dimension outcomes and responses

\begin{tabular}{|c|c|c|c|c|c|}
\hline $\begin{array}{l}\text { Technology acquisition } \\
\text { efforts }\end{array}$ & Frequency & Outcome & Learning efforts & Frequency & Outcome \\
\hline \multirow{5}{*}{$\begin{array}{l}\text { TM tools being used } \\
\text { Skills audit exercises } \\
\text { conducted } \\
\text { Technology acquisition } \\
\text { brings news skills } \\
\text { Right technologies being } \\
\text { acquired } \\
\text { Technology switch done } \\
\text { on time }\end{array}$} & Partial & Partial & \multirow{5}{*}{$\begin{array}{l}\text { Knowledge sharing } \\
\text { Cross-functional } \\
\text { collaboration } \\
\text { Skills knowledge transfer }\end{array}$} & Weak & Weak \\
\hline & Weak & Weak & & Partial & Partial \\
\hline & Partial & Partial & & Partial & Partial \\
\hline & Partial & Partial & & Weak & Weak \\
\hline & Partial & Partial & & Partial & Partial \\
\hline Innovative capacity & Frequency & Outcome & TM limiting factors & Frequency & Outcome \\
\hline \multirow{3}{*}{$\begin{array}{l}\text { Search for innovative } \\
\text { ways } \\
\text { Log innovative ideas } \\
\text { Implement new ideas }\end{array}$} & Partial & Partial & \multirow{4}{*}{$\begin{array}{l}\text { Business operating model } \\
\text { Too many standalone } \\
\text { systems } \\
\text { Organisational } \\
\text { systems/processes } \\
\text { Many years of experience } \\
\text { Higher levels of education }\end{array}$} & Weak & Weak \\
\hline & Partial & Partial & & Partial & Partial \\
\hline & Partial & Partial & & Good & Partial \\
\hline & & & & Partial & Partial \\
\hline
\end{tabular}

Based on the interview process, it was found that, when learning occurs and the employees are competent, there is a flow of knowledge to their peers. However, in the case of DWSS, poor levels of knowledge transfer resulted in an increased number of failed incidents in the production environments. Additionally, poor knowledge codification caused a semi-utilisation of technology because tacit knowledge was not being transferred. Thus, when people leave the organisation, such knowledge is lost. It was further found that capability assessments through skills audit exercises are associated with better technology acquisition practices. By contrast, if these are not done, the organisation acquires technology that is not in line with its strategic direction.

Based on the qualitative interview evidence, using AtlasTI software, a consolidated network was constructed, and the following relationship structure was identified:

Organisation is associated with:

(i) Learning modes / Skills transfer modes, causing:

(a) Failure incidents generators

(b) TM tools hindrance 
(c) Knowledge codification hindrance

(ii) Technology certification mode / Capability assessment, causing:

(a) Non-technological fit

(b) Innovation logging hindrance

(iii) Innovation drivers / Knowledge codification, causing:

(a) Technology semi-utilisation

\subsection{Hypothesis testing}

Spearman's correlation statistical tests for quantitative data were conducted, and are summarised in Table 3 below. They demonstrate that the null hypothesis for all of the dimensions can be ignored. This is based on the $p$-value, which is significant at $p<0.05$, indicating that less than five per cent of the outcomes could have been obtained by chance. The correlation measures the strength and the direction of the associations between two ordinal variables. It takes the values of +1 and -1 for strong positive and negative correlations respectively.

Table 3: Spearman's dimensions outcomes

\begin{tabular}{|l|l|l|l|l|}
\hline Dimension & $\begin{array}{l}\text { Spearman's } \\
\text { correlation } \\
(\mathbf{r})\end{array}$ & $\begin{array}{l}\text { Statistical } \\
\text { significance } \\
\text { (p-value) }\end{array}$ & Outcome & $\begin{array}{l}\text { Hypothesis } \\
\text { acceptance }\end{array}$ \\
\hline Technology acquisition efforts & 0.315 & 0.042 & Moderate & Partial \\
\hline Learning efforts & 0.527 & 0.000 & Moderate & Partial \\
\hline Innovative capability & 0.672 & 0.000 & Moderate & Accepted \\
\hline Usage of TM limiting factors & 0.347 & 0.025 & Moderate & Partial \\
\hline $\begin{array}{l}\text { Partial correlation on learning } \\
\text { and innovative capability }\end{array}$ & 0.688 & 0.000 & Moderate & Partial \\
\hline
\end{tabular}

From the qualitative study, it was noted that technology acquisition was associated with building capabilities within the organisation. Combining this with technology acquisition efforts from the Spearman calculations confirms that the following should be accepted:

\section{H1: Use of space maps and s-curve in technology acquisition has a positive effect on technology optimisation in the bank under study.}

Learning was also found to increase competence and internal capacity. In instances where it did not occur, there was no codification of knowledge, resulting in increased failure incidents in production and semi-utilised technology. Consequently, combined with the quantitative analysis results, the following is accepted:

H2: Learning dimensions of knowledge codification, knowledge articulation, and experience accumulation have a positive effect on technology optimisation in the bank under study.

The results of the quantitative analysis showed a strong correlation between innovative capabilities and technology acquisition, with a Spearman's value of 0.672 . It was concluded that technology acquisition brings new skills sets, and thus contributes to improving the innovative capabilities of the organisation. As such, the following is accepted:

\section{H3: Improvement of technology acquisition process has a positive effect on the innovative capability of the bank under study.}

The partial correlation of learning and innovative capabilities on technology optimisation was found to be significantly strong. Consequently, this resulted in increased failure incidents in the production environment and in semi-utilised technologies.

H4: Learning and innovative capabilities in the bank under study have a moderating role on the relationship between technology acquisition and optimisation.

For each of the research questions, the following conclusions were reached:

How can technology management activities be used to optimise technology utilisation in the banking industry? 
With technology acquisition and learning selected as technology management activities for this study, it was found that - based on Spearman's statistical significance p-value of $0.042<0,05$ - the null hypothesis could be ignored. The correlation factor of 0.315 meant that, based on the sample size that was conducted, the results were inconclusive. However, on the question about whether technology acquisition was bringing new skillsets to the organisation, the responses indicated a median of 4 - that is, 'agree to strongly agree' to the statements. A qualitative study delved deeper into the factors driving the low perception on the dimensions, and found that various forms of learning were taking place and building the absorptive capabilities required to deliver customer requirements. A factor that was found to be lacking was knowledge codification and cross-functional knowledge transfer across teams. Similarly, limited surveillance activities on emerging technologies were being conducted, with the majority been done through suppliers' advice. This causes a partial utilisation of technology across the department because of a technology mismatch, as the technology was not always in line with what the department wanted to accomplish. It thus indicated that, when learning and technology acquisition are put in place, technology optimisation is increased; and this answered the research question.

\section{How can technology acquisition processes be optimised?}

It was found during the qualitative research on questions of how technology acquisition was conducted that it was mostly driven by current suppliers. They suggested new tools, or the group technology team led the way on what technology needed to be acquired; and this created a mismatch between the current skillset in the department and the capabilities that needed to be developed internally. This was exacerbated by an ad hoc skills assessment at performance review times, which mostly happened late in the year when the bulk of the projects were already under way. Similarly, only about 40 per cent of the respondents knew about technology tools such as Scurve, and believed that they were being used in the department. This was further supported by some respondents who mentioned during the qualitative interviews that the right technologies were not always acquired by the department. This implies that the increased use of skills audit exercises and tools such as technology maps will assist in making more informed decisions and optimising the acquisition of technologies within the department. This therefore answered the research question about how the acquisition processes within the department could be optimised.

\section{What factors hinder the effective use of TM tools in the banking industry?}

The business operating model, which is based on different functional areas, was found to contribute most to the hindrances, with some respondents in the interview sessions mentioning that this leads to a lack of knowledge sharing across the teams. An in-depth enquiry found that teams felt that they belonged more to their functional teams, and were not willing to share their skills freely with the other teams. Additionally, high levels of experience on specific technologies, especially legacy systems such as COBOL, contributed to the problem. This is because resources with these skills were not willing to learn new technologies, as they wanted to focus on their core skills - mainly because these are in short supply in the market, despite being core to the banking sector applications. This is further compounded by regulations that require retirement at the age of 60 , thus creating no motivation to learn other tools that are specific to the banking industry while they are close to leaving it.

\section{What impact does technology acquisition have on the innovative capability of the organisation?}

The conceptual model adopted earlier in the study, and the findings of the quantitative study, showed that technology acquisition brought new skillsets to the division. This is supported by the findings that all the employees conducted some form of research to find innovative solutions to problems, and that more than 80 per cent agreed that they sometimes, often, or always implemented those ideas. This demonstrated that the department's innovative abilities are greatly enhanced by technology acquisition efforts. The study further found that the innovative capabilities did not translate directly into innovations being logged, despite being implemented. Further information obtained through the qualitative study highlighted that the logging process was perceived to be reliant on other employees nominating the innovations; and this did not help, as those employees did not have enough information about the implemented innovations. Also, there 
appeared to be a lack of interest once the innovation had been implemented to get it known across the teams; thus most of them were never logged.

Several recommendations can be made for future research on the use of technology management activities and tools in the banking industry. Since this study was limited to the DWSS division in one of the large South African banks, similar studies could be conducted in other divisions of the bank, especially those divisions that potentially have an impact on innovation. In addition, similar studies could be conducted in the other large banks in South Africa. Important learnings from such comparative studies could benefit the competitiveness of the broader banking industry in South Africa, without negatively impacting their respective competitive positions. Another important topic for future research is the development of research models in which the innovation ecosystem theory plays a much more prominent role. It is clear from the findings of this research that innovation efforts that are mainly focused on internal capabilities are not necessarily the optimum route to go. External suppliers can also make a substantial contribution to the innovation successes of a firm.

\section{REFERENCES}

[1] Pretorius, M. W. 2000. Technology assessment in the manufacturing enterprise: A holistic approach. Proceedings of the 9th International Conference on Management of Technology, pp. 21-25.

[2] Eisenhardt, K. M. \& Martin, J. A. 2000. Dynamic capabilities: What are they? Strategic Management Journal, 21(10-11), pp. 1105-1121.

[3] Çetindamar, D., Phaal, R. \& Probert, D. 2010. Technology management: Activities and tools. Palgrave Macmillan, London

[4] Teece, D. J., Pisano, G. \& Shuen, A. 1997. Dynamic capabilities and strategic management. Strategic Management Journal, 18 (7), pp. 509-533.

[5] Valkokari, K. \& Ketonen-Oksi, S. 2018. Understanding platforms and ecosystems as structures for value co-creation, Proceedings of The ISPIM Innovation Conference, Stockholm, Sweden, 17-20 June 2018.

[6] Adner, R. 2006. Match your innovation strategy to your innovation ecosystem. Harvard Business Review, 84(4), pp. 98-107.

[7] Mortara, L. \& Ford, S. 2012. Technology acquisitions: A guided approach to technology acquisition and protection decisions, Workbook published by the IfM, Cambridge University, Cambridge, UK.

[8] Tsai, K.-H. \& Wang, J.-C. 2008. External technology acquisition and firm performance: A longitudinal study. Journal of Business Venturing, 23(1), pp. 91-112.

[9] Yu, S.-H. 2013. Social capital, absorptive capability, and firm innovation. Technological Forecasting and Social Change, 80(7), pp. 1261-1270.

[10] Farrukh, M. \& Waheed, A. 2015. Learning organization and competitive advantage: An integrated approach. Journal of Asian Business Strategy, 5(4), pp. 73.

[11] Appelbaum, S. H. \& Gallagher, J. 2000. The competitive advantage of organizational learning. Journal of Workplace Learning, 12(2), pp. 40-56.

[12] Kang, K. H., Jo, G. S. \& Kang, J. 2015. External technology acquisition: A double-edged sword. Asian Journal of Technology Innovation, 23(1), pp. 35-52.

[13] Boerner, C. S., Macher, J. T. \& Teece, D. J. 2001. A review and assessment of organizational learning in economic theories. In Handbook of Organizational Learning and Knowledge, Dierkes, Berthoin-Antal Child and Nonaka, Eds., Oxford University Press, pp. 89-117.

[14] Çetindamar, D., Wasti, N. S. \& Beyhan, B. 2012. Technology management tools and techniques: Factors affecting their usage and their impact on performance. International Journal of Innovation and Technology Management, 9(5).

[15] Zollo, M. \& Winter, S. G. 2002. Deliberate learning and the evolution of dynamic capabilities. Organization Science, 13(3), pp. 339-351.

[16] De Wet, G. 1995. Technology space maps for technology management and audits. Management of Technology, III, pp. 1235-1243.

[17] Foden, J. \& Berends, H. 2010. Technology management at Rolls-Royce. Research-Technology Management, 53(2), pp. 33-42.

[18] Liao, S. H., Wu, C. C., Hu, D. C. \& Tsui, K. A. 2010. Relationships between knowledge acquisition, absorptive capacity and innovation capability: An empirical study on Taiwan's financial and manufacturing industries. Journal of Information Science, 36(1), pp. 19-35.

[19] Neely, A. \& Hii, J. 2012. The innovative capacity of firms. Nang Yan Business Journal, 1(1), pp. 47-53.

[20] Jiménez-Jiménez, D. \& Sanz-Valle, R. 2011. Innovation, organizational learning, and performance. Journal of Business Research, 64(4), pp. 408-417.

[21] Tsai, M.-T. \& Tsai, C.-L. 2010. Innovation capability and performance in Taiwanese science parks: Exploring the moderating effects of industrial clusters fabric. International Journal of Organizational Innovation, 2(4), pp. 80-103.

[22] Cohen, W. M. \& Levinthal, D. A. 1990. Absorptive capacity: A new perspective on learning and innovation. Administrative Science Quarterly, pp. 128-152. 
[23] Yeșil, S., Koska, A. \& Büyükbeșe, T. 2013. Knowledge sharing process, innovation capability and innovation performance: An empirical study. Procedia - Social and Behavioral Sciences, 75, pp. 217 225.

[24] Magoutas, A. I., Agiomirgianakis, G. M. \& Papadogonas, T. A. 2011. Education and firm performance. Empirical evidence from Greece. International Journal of Economic Research, 8(2), pp. 141-152.

[25] Creswell, J. W. \& Clark, V. L. P. 2007. Designing and conducting mixed methods research, $2^{\text {nd }}$ ed., SAGE publications, Thousand Oaks, California, USA.

[26] Runeson, P. \& Höst, M. 2009. Guidelines for conducting and reporting case study research in software engineering. Empirical Software Engineering, 14(2), pp. 131-164.

[27] Palinkas, L. A., Horwitz, S. M., Green, C. A., Wisdom, J. P., Duan, N. \& Hoagwood, K. 2015. Purposeful sampling for qualitative data collection and analysis in mixed method implementation research. Administration and Policy in Mental Health and Mental Health Services Research, 42(5), pp. 533-544.

[28] Creswell, J. W. 2013. Research design: Qualitative, quantitative, and mixed methods approaches. Sage Publications, Thousand Oaks, California, USA.

[29] Thayer-Hart, N., Dykema, J., Elver, K., Schaeffer, N. \& Stevenson, J. 2010. Survey fundamentals: A guide to designing and implementing surveys. Office of Quality Improvement, University of Wisconsin Survey Center Madison, WI, USA , p20.

[30] Tavakol, M. \& Dennick, R. 2011. Making sense of Cronbach's alpha. International Journal of Medical Education, 2, pp. 53.

[31] Bernard, H. R. 2011. Research methods in anthropology: Qualitative and quantitative approaches. Rowman Altamira, Lanham, Maryland, USA.

[32] Krippendorff, K. 2012. Content analysis: An introduction to its methodology. Sage, Thousand Oaks, California, USA.

[33] Palys, T. 2008. Purposive sampling. The Sage Encyclopedia of Qualitative Research Methods, Lisa M. Given Editor, Vol. 2, SAGE, Thousand Oaks, California, USA, pp. 697-698. 


\begin{tabular}{|l|l|l|l|l|l|l|}
\hline \multicolumn{7}{|l|}{ Dimension: Innovative capability efforts } \\
\hline & At work, how often do the following happen? & Sometimes & Often & Always \\
\hline 1.1 & $\begin{array}{l}\text { Search for new innovative } \\
\text { ways of doing things }\end{array}$ & Rarely & & & & \\
\hline 1.2 & $\begin{array}{l}\text { Log innovative ideas in } \\
\text { innovation platforms available } \\
\text { in the organization }\end{array}$ & & & & & \\
\hline 1.3 & Implement new ideas & & & & & \\
\hline
\end{tabular}

\begin{tabular}{|c|c|c|c|c|c|c|}
\hline & \multicolumn{6}{|c|}{ Dimension: Technology acquisition efforts } \\
\hline & \multicolumn{6}{|c|}{ To what extend do you agree/disagree with the following statements? } \\
\hline & & Never & Rarely & Sometimes & Often & Always \\
\hline 2.1 & $\begin{array}{l}\text { Right technologies are acquired } \\
\text { for the intended purposes }\end{array}$ & & & & & \\
\hline 2.2 & $\begin{array}{l}\text { Technology switch to next } \\
\text { generation technologies is } \\
\text { informed by current } \\
\text { technologies becoming obsolete }\end{array}$ & & & & & \\
\hline 2.3 & $\begin{array}{l}\text { Technology acquisitions bring } \\
\text { new skills to the department }\end{array}$ & & & & & \\
\hline 2.4 & $\begin{array}{l}\text { Some level R/D (Research and } \\
\text { development) happen, } \\
\text { contributing to new knowledge } \\
\text { and skills acquisition }\end{array}$ & & & & & \\
\hline 2.5 & $\begin{array}{l}\text { Technology acquisitions are } \\
\text { mostly from external partners }\end{array}$ & & & & & \\
\hline 2.6 & $\begin{array}{l}\text { Skills and knowledge transfer } \\
\text { are key prerequisites for } \\
\text { vendors to deliver in technology } \\
\text { acquisitions }\end{array}$ & & & & & \\
\hline 2.7 & $\begin{array}{l}\text { Technology management } \\
\text { tools/techniques such as } \\
\text { technology road mapping, S- } \\
\text { curve, benchmarking, root } \\
\text { cause effect analysis, AGILE } \\
\text { methodologies are used in the } \\
\text { department }\end{array}$ & & & & & \\
\hline
\end{tabular}

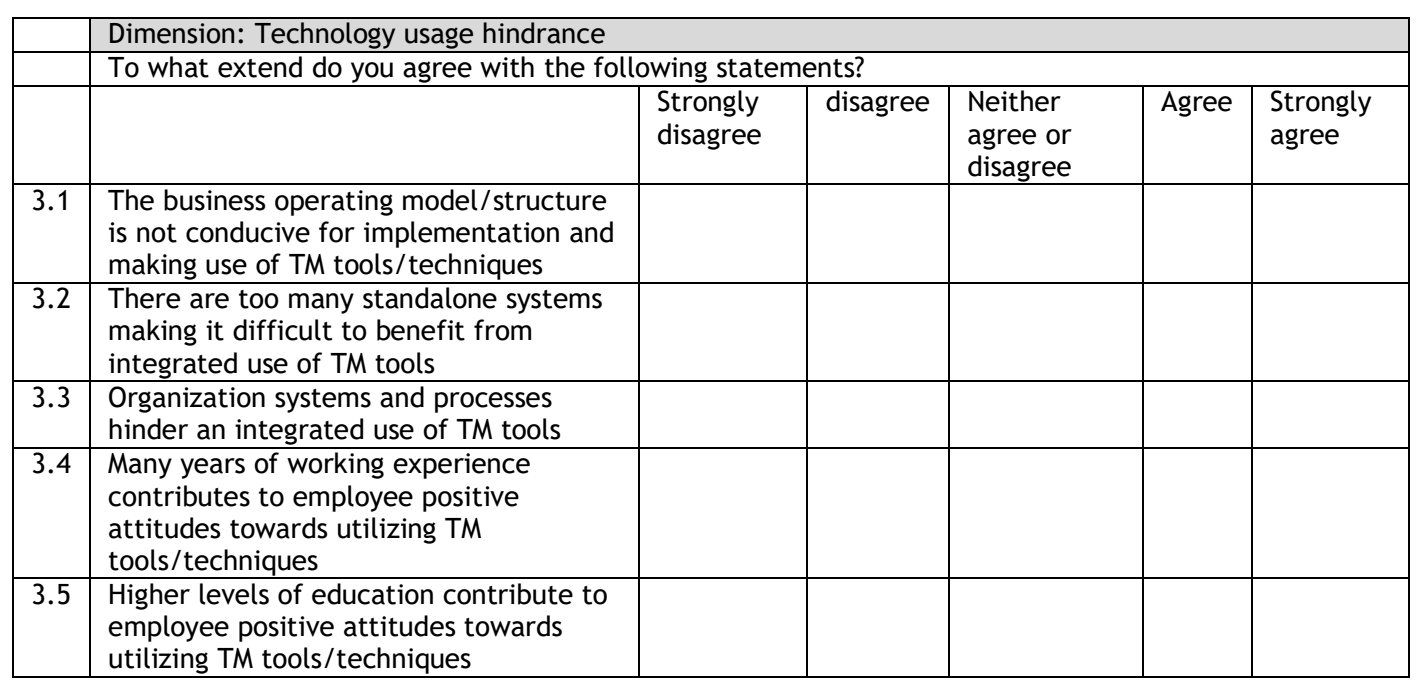




\begin{tabular}{|c|c|c|c|c|c|c|c|}
\hline & \multicolumn{7}{|l|}{ Dimension: Learning efforts } \\
\hline & & \multicolumn{2}{|c|}{$\begin{array}{l}\text { Strongly } \\
\text { disagree }\end{array}$} & disagree & $\begin{array}{l}\text { Neither } \\
\text { agree or } \\
\text { disagree }\end{array}$ & Agree & $\begin{array}{l}\text { Strongly } \\
\text { agree }\end{array}$ \\
\hline 4.1 & $\begin{array}{l}\text { Self-learning and course attendance } \\
\text { training happen to keep abreast with the } \\
\text { latest technologies }\end{array}$ & & & & & & \\
\hline 4.2 & $\begin{array}{l}\text { Learning by experimenting happens in } \\
\text { the organization }\end{array}$ & & & & & & \\
\hline 4.3 & $\begin{array}{l}\text { Employees are qualified/certified in } \\
\text { technologies they work with in daily } \\
\text { routines }\end{array}$ & & & & & & \\
\hline 4.4 & $\begin{array}{l}\text { Wealth of knowledge available in the } \\
\text { organization is codified and stored in } \\
\text { easily accessible platforms for reuse and } \\
\text { learning }\end{array}$ & & & & & & \\
\hline 4.5 & $\begin{array}{l}\text { Post implementation reviews happen to } \\
\text { learn from mistakes and improve } \\
\text { efficiency in subsequent projects }\end{array}$ & & & & & & \\
\hline \multirow[t]{4}{*}{4.6} & $\begin{array}{l}\text { Quality standards are adhered to and } \\
\text { applied across the teams }\end{array}$ & & & & & & \\
\hline & \multicolumn{7}{|c|}{ Dimension: Technology exploitation efforts } \\
\hline & \multicolumn{7}{|c|}{ To what extend do you agree with the following statements? } \\
\hline & & Never & $\begin{array}{l}\text { Almost } \\
\text { never }\end{array}$ & $\begin{array}{l}\text { Occasi } \\
\text { someti }\end{array}$ & $\begin{array}{l}\text { onally/ } \\
\text { imes }\end{array}$ & $\begin{array}{l}\text { Almost } \\
\text { every } \\
\text { time }\end{array}$ & $\begin{array}{l}\text { Every } \\
\text { time }\end{array}$ \\
\hline 5.1 & $\begin{array}{l}\text { How often do solutions rework } \\
\text { happen after solutions are } \\
\text { commissioned to production? }\end{array}$ & & & & & & \\
\hline 5.2 & $\begin{array}{l}\text { Reworks happen because of } \\
\text { requirements that were not } \\
\text { documented }\end{array}$ & & & & & & \\
\hline 5.3 & $\begin{array}{l}\text { Reworks happen because of tasks not } \\
\text { implemented correctly }\end{array}$ & & & & & & \\
\hline 5.4 & $\begin{array}{l}\text { Reworks happen because of changing } \\
\text { customer requirements }\end{array}$ & & & & & & \\
\hline 5.5 & $\begin{array}{l}\text { Reworks happen because of issues } \\
\text { related to different environmental } \\
\text { problems }\end{array}$ & & & & & & \\
\hline 5.6 & $\begin{array}{l}\text { Reworks happen because solutions } \\
\text { fail in production environments }\end{array}$ & & & & & & \\
\hline 5.7 & $\begin{array}{l}\text { Receive positive feedback customers } \\
\text { based on work/projects delivered }\end{array}$ & & & & & & \\
\hline 5.8 & $\begin{array}{l}\text { Get escalated based on substandard } \\
\text { quality of work on projects/work } \\
\text { delivered }\end{array}$ & & & & & & \\
\hline
\end{tabular}

